\title{
KANDUNGAN LOGAM BERAT KERANG DARAH (Anadara granosa) DAN KUALITAS PERAIRAN DI TANJUNG PASIR, JAWA BARAT
}

\author{
Jovita Tri Murtini dan Farida Ariyani")
}

\begin{abstract}
ABSTRAK
Telah dilakukan penelitian kandungan logam berat pada perairan dan kerang darah (Anadara granosa) serta kualitas perairan di Tanjung Pasir, Jawa Barat pada bulan Juni dan Oktober 2001. Penelitian dilakukan di enam stasiun, tiga stasiun berjarak satu mil dan tiga lainnya berjarak dua mil dari garis pantai. Antar stasiun berjarak satu mil. Contoh yang diambil meliputi air laut, sedimen dan kerang darah. Contoh dianalisis secara kimia (kandungan logam berat yaitu merkuri, arsen, kadmium, tembaga dan timbal serta kualitas air yang meliputi $\mathrm{pH}, \mathrm{DO}, \mathrm{COD}$, dan salinitas) serta mikrobiologi ( $E$. coli). Hasil penelitian menunjukkan bahwa pada saat pengambilan contoh, perairan Tanjung Pasir masih belum menunjukkan kecenderungan terjadinya pencemaran. Kandungan logam berat yaitu merkuri, arsen, kadmium, tembaga dan timbal pada kekerangan yang hidup di perairan tersebut masih di bawah ambang batas yang ditentukan $(0,5$ ppm untuk $\mathrm{Hg}$ ). Disamping itu kekerangan dari perairan tersebut juga belum terkontaminasi oleh bakteri E.coli.
\end{abstract}

\begin{abstract}
Heavy metal content in blood cockle (Anadara granosa) and waters quality in Tanjung Pasir, West Java. By: Jovita Tri Murtini and Farida Ariyani

Study on heavy metal content both in waters and cockles caught at Tanjung Pasir, West Java and its waters quality was conducted on June and October 2001. Observation was carried out at 6 stasions; 3 stations were 1 mile while 3 others were 2 miles from coastal line. The distances between stations were aproximately one mile. Samples taken from each station were cockles, water and sediment and analyzed chemically (heavy metals i.e. $\mathrm{Hg}, \mathrm{As}, \mathrm{Cd}, \mathrm{Cu}$ and Pb as well as water quality i.e. $\mathrm{pH}, \mathrm{DO}, \mathrm{COD}$ and salinity), and microbiologically ie.E.coli. The result showed that by the time, Tanjung Pasir waters were not contaminated. The heavy metals $(\mathrm{Hg}, \mathrm{As}, \mathrm{Cd}, \mathrm{Cu}$, and $\mathrm{Pb}$ ) content of cockles were also still bellow the standard limit, while no contamination by $E$. coli was detected.
\end{abstract}

KEYWORDS: heavy metal, Anadara granosa, Tanjung Pasir waters

\section{PENDAHULUAN}

Pada era perdagangan global, produk-produk Indonesia termasuk produk perikanan harus mampu bersaing dengan produk perikanan dari negara lain. Kualitas dan keamanan pangan produk-produk perikanan merupakan hal yang sangat penting dan perlu diperhatikan dalam hubungannya dengan dibukanya perdagangan bebas, karena menyangkut kepercayaan konsumen dalam dan luar negeri terhadap produk yang dihasilkan. Jaminan kualitas dan keamanan menjadi hal yang sangat penting pada produk perikanan. Penyebab tidak amannya suatu produk untuk dikonsumsi adalah akibat adanya senyawa/bahan kimia, mikroorganisme dan cemaran fisik berbahaya yang tidak dikehendaki keberadaannya atau jumlahnya melebihi ketentuan yang telah ditetapkan (Irianto \& Poernomo, 2000). Keamanan produk konsumsi ini perlu diperhatikan untuk menjaga kepercayaan konsumen dalam dan luar negeri terhadap produk yang dihasilkan Indonesia. Dalam bidang ekspor produk perikanan, Indonesia menempati urutan nomor dua dari sebelas negara pengekspor dalam hal jumlah penolakan dari FDA selama 4 bulan dari Mei s/d Agustus 1998. Sedangkan alasan penolakan adalah Salmonella, kotoran, benda asing dan zat beracun (Raharjo, 1999).

Senyawa/bahan kimia, mikroorganisme dan cemaran fisik berbahaya yang terdapat pada produk perikanan antara lain disebabkan oleh lingkungan tempat hidup ikan, termasuk lokasi budidaya. Logam berat terutama merkuri merupakan bahan cemaran yang perlu diwaspadai karena dapat menimbulkan efek akumulatif seperti halnya penyakit Minamata di Jepang (Anon., 2000). Pada daerah perairan yang berdampingan/berdekatan dengan industri berat diduga tingkat pencemarannya lebih tinggi

- Peneliti pada Balai Besar Riset Pengolahan Produk dan Bioteknologi Kelautan dan Perikanan 
dibandingkan dengan perairan yang tidak berdekatan dengan industri berat. Hal ini disebabkan senyawa logam berat banyak digunakan dalam industri sebagai bahan baku, katalisator, fungisida maupun bahan tambahan (additives) lainnya (Hutagalung, 1984). Menurut FDA di dalam Anon. (1998), selain merkuri $(\mathrm{Hg})$, jenis logam berat yang membahayakan kesehatan antara lain timbal $(\mathrm{Pb})$, kadmium $(\mathrm{Cd})$, arsen (As), khromiun ( $\mathrm{Cr}$ ) dan nikel (Ni). Jenis biota laut yang sangat potensial terkontaminasi logam berat adalah kekerangan mengingat cara makannya dengan menyaring air. Disamping itu, sifat kekerangan ini lebih banyak menetap (sessile) dan bukan termasuk migratory (Wahyuni \& Hartati 1991), sehingga biota ini sering digunakan sebagai hewan uji dalam pemantauan tingkat akumulasi logam berat pada organisme laut.

Penelitian mengenai kandungan logam berat pada beberapa jenis kekerangan di beberapa perairan di Indonesia telah dilakukan oleh peneliti terdahulu. Menurut Irianto et al.(1987), kandungan merkuri pada kerang tahu dan kerang gundul yang dipanen di perairan Cilamaya, Subang-Jawa Barat sebesar 0,27 ppm dan 0,24 ppm. Kadar merkuri ini masih di bawah ambang batas $0,5 \mathrm{ppm}$ (Graham, 1980). Wahyuni et al.(1993) menyatakan bahwa kandungan logam berat kerang hijau di pantai Dadap (Teluk Jakarta) pada bulan Juli 1991 sebesar 1,4 ppm, jauh melebihi ambang batas yang diperbolehkan, tetapi pada bulan November kandungan logam berat pada kerang hijau tersebut telah menurun menjadi sebesar 0,39 ppm. Sampai dengan saat ini, data lengkap mengenai kandungan merkuri pada produk perikanan di Indonesia belum tersedia. Dengan demikian untuk melengkapi hasil penelitian terdahulu mengenai kandungan logam berat pada biota dalam hubungannya dengan pencemaran daerah perairan tempat pertumbuhannya, diperlukan penelitian lebih lanjut yang lebih dikonsentrasikan pada jenis kekerangan. Di Tanjung Pasir banyak hidup kerang darah dan banyak di antaranya dikonsumsi oleh konsumen lokal. Di lain pihak, Tanjung Pasir merupakan bagian dari Teluk Jakarta yang kemungkinan merupakan daerah yang tercemar karena pembuangan limbah dari industri di Jakarta. Oleh karena itu, pengamatan secara menyeluruh terhadap lingkungan dan biota yang hidup di dalamnya perlu dilakukan untuk mendapat gambaran mengenai perairan dan keamanan biota atau produk perikanan yang dihasilkan.

\section{BAHAN DAN METODE}

Bahan utama yang digunakan adalah air laut dan sedimen serta kerang darah (Anadara granosa) yang diambil dari perairan Tanjung Pasir, Jawa Barat. Bahan bantu untuk penelitian adalah semua bahan-bahan kimia yang diperlukan untuk analisis logam berat dan COD dan juga bahan media untuk analisis $E$. coli. Disamping itu juga es untuk pendinginan contoh agar tidak cepat rusak.

Contoh diambil di 6 stasiun, yaitu tiga stasiun berjarak 1 mil dari garis pantai dan 3 stasiun lain berjarak 2 mil dari garis pantai dengan jarak antar stasiun 1 mil. Penetapan stasiun berdasarkan peta laut yang dikeluarkan oleh Dinas Hidro Oseanografi TNI AL No. 86 cetakan ke XI September 1999 untuk perairan Teluk Jakarta. Posisi lokasi pengambilan contoh ditentukan menggunakan peralatan GPS (Global Positioning System). Identifikasi logam berat dilakukan untuk merkuri $(\mathrm{Hg})$, timbal $(\mathrm{Pb})$, kadmium (Cd), tembaga (Cu) dan arsen (As). Analisis terhadap logam berat pada sampel dilakukan menggunakan AAS (Atomic Absorption Spectrophotometer) (Hutagalung et al., 1997). Disamping logam berat, juga dilakukan analisis mutu baku air untuk DO dan suhu (menggunakan DO meter), COD (menggunakan metode titrasi), $\mathrm{pH}$ (menggunakan $\mathrm{pH}$ meter) dan salinitas (menggunakan refraktometer) dari perairan setempat. Disamping itu dilakukan analisis bakter pencemar yaitu E. coli dengan metode MPN (Yong, 1992). Pengamatan dilakukan dua kali selama waktu penelitian, pada waktu musim timur (bulan Juni 2001) dan musim peralihan (bulan Oktober 2001). Lokasi pengambilan contoh di Tanjung Pasir adalah di muara Sungai Kalong dengan posisi pengambilan contoh berdasarkan peta laut yang telah ditentukan posisinya yang tepat untuk 6 stasiun seperti disajikan pada Tabel 1.

\section{HASIL DAN BAHASAN}

Hasil analisis kadar merkuri pada air laut dan sedimen disajikan pada Gambar 1. Kadar merkuri air laut di perairan Tanjung Pasir pada bulan Juni dan Oktober baik pada stasiun berjarak 1 mil maupun 2 mil tidak banyak berbeda yaitu $0,96-1,35 \mathrm{ppb}$. Kadar merkuri tersebut masih di bawah ambang batas yang diperbolehkan (3 ppb). Pada bulan Juni kadar merkuri sedimen pada stasiun yang berjarak 1 mil sebesar $38,50 \mathrm{ppb}$, lebih tinggi dibandingkan dengan sedimen pada stasiun yang berjarak 2 mil. Hal ini kemungkinan karena limbah dari sungai lebih banyak mengendap pada jarak 1 mil sedangkan pada jarak 2 mil, pengendapan limbah lebih sedikit karena adanya pengaruh arus laut. Berbeda dengan kadar merkuri pada air laut, kadar merkuri pada sedimen cukup tinggi. Kandungan merkuri pada sedimen yang diambil pada bulan Oktober jauh lebih rendah daripada kandungan merkuri pada sedimen yang diambil pada bulan Juni. Hal ini kemungkinan disebabkan telah terjadinya arus bawah yang besar yang 
Tabel 1. Posisi stasiun pengambilan contoh

Table 1. Sampling stations position

\begin{tabular}{ccc}
\hline $\begin{array}{c}\text { Stasiun/ } \\
\text { Station }\end{array}$ & $\begin{array}{c}\text { Lintang Selatan/ } \\
\text { South Latitude }\end{array}$ & $\begin{array}{c}\text { Bujur Timur/ } \\
\text { East Meridien }\end{array}$ \\
\hline 1 & $06^{\circ} 01^{\prime} 09^{\prime \prime}$ & $106^{\circ} 42^{\prime} 10^{\prime \prime}$ \\
2 & $06^{\circ} 00^{\prime} 33^{\prime \prime}$ & $106^{\circ} 41^{\prime} 15^{\prime \prime}$ \\
3 & $06^{\circ} 00^{\prime} 06^{\prime \prime}$ & $106^{\circ} 40^{\prime} 30^{\prime \prime}$ \\
4 & $06^{\circ} 59^{\prime} 06^{\prime \prime}$ & $106^{\circ} 41^{\prime} 00^{\prime \prime}$ \\
5 & $06^{\circ} 59^{\prime} 48^{\prime \prime}$ & $106^{\circ} 41^{\prime} 54^{\prime \prime}$ \\
6 & $06^{\circ} 00^{\prime} 18^{\prime \prime}$ & $106^{\circ} 42^{\prime} 42^{\prime \prime}$ \\
\hline
\end{tabular}

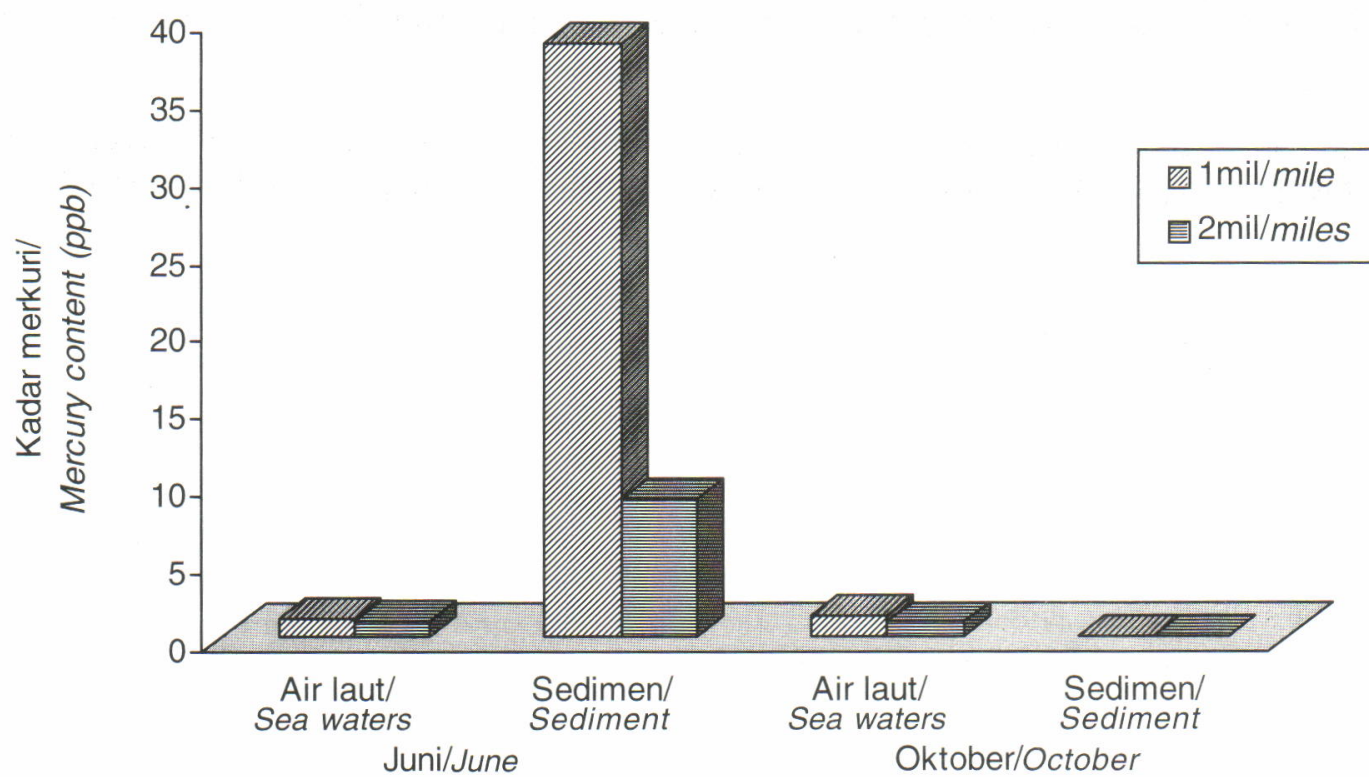

Gambar 1. Kadar merkuri (ppb) air laut dan sedimen di perairan Tanjung Pasir.

Figure 1. Mercury content ( $p p b)$ of sea water and sediment in Tanjung Pasir waters.

mengakibatkan terangkatnya atau berpindahnya sedimen tersebut ke tempat lain.

Kandungan logam berat $(\mathrm{Hg}, \mathrm{As}, \mathrm{Cd}$, Cu dan $\mathrm{Pb})$ pada kerang darah (Anadara granosa) dari perairan Tanjung Pasir disajikan pada Gambar 2. Apabila dibandingkan dengan hasil analisis pada air laut dan sedimen, kandungan merkuri pada kekerangan $(9,93$ $\mathrm{ppb})$ lebih tinggi dari kandungan pada air laut $(0,96-$ $1,35 \mathrm{ppb}$ ) tetapi lebih rendah dari kandungan merkuri dalam sedimen (8,94-38,53 ppb). Meskipun kadar merkuri pada kekerangan ini masih di bawah batas yang diijinkan oleh SNI (500 ppb), tetapi hal ini perlu diwaspadai kerena sifat merkuri tersebut terakumulasi sedikit demi sedikit di dalam tubuh manusia terutama pada ginjal, hati dan otak (Tsubaki \& Irukayama, 1977). Untuk mencegah pencemaran merkuri dalam kekerangan dapat dilakukan dengan mengontrol pembuangan limbah industri yang mengandung logam berat. Merkuri terdapat di alam dalam bentuk logam merkuri, ion merkuri dan senyawa organik merkuri. Organik merkuri berikatan secara kovalen dengan karbon misalnya alkil merkuri, metilmerkuri atau etilmerkuri. Alkil merkuri larut dalam lemak dan tahan terhadap biodegradasi. Menurut Depkes RI batas maksimum cemaran dalam makanan untuk merkuri $(\mathrm{Hg})$ adalah 0,5 ppm dan $\mathrm{Pb} 2 \mathrm{ppm}$. Untuk mengurangi 


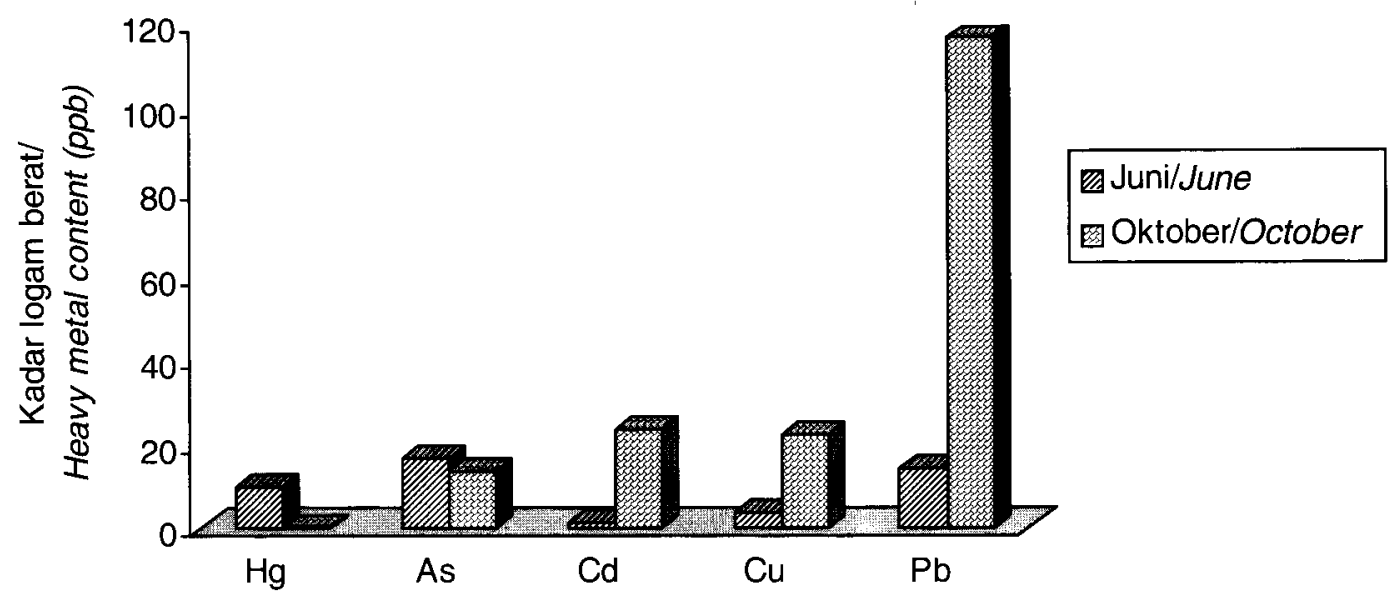

Gambar 2. Kadar logam berat kerang darah (Anadara granosa) di perairan Tanjung Pasir. Figure 2. Heavy metal content of blood cockle (Anadara granosa) in Tanjung Pasir waters.

kandungan merkuri dalam kekerangan dapat dilakukan dengan mengontrol pembuangan limbah industri ke laut.

Pada Gambar 2 terlihat bahwa kandungan arsen (As) kerang darah pada bulan Juni adalah $16,59 \mathrm{ppb}$ dan bulan Oktober 13,65 ppb. Kadmium (Cd) 1,18 ppb pada bulan Juni dan 23,33 ppb pada bulan Oktober. Menurut the National Food Authority (NFA) dalam Anon. (1995), kandungan maksimum kadmium (Cd) dan arsen (As) pada kekerangan yang diijinkan masing-masing adalah $2000 \mathrm{ppb}$ dan $1000 \mathrm{ppb}$. Dengan demikian kandungan arsen maupun kadmium pada kekerangan dari perairan Tanjung Pasir masih pada tingkat yang diperbolehkan. Secara alami kadmium biasanya berada pada suatu mineral bersama dengan seng $(Z n)$, dengan kandungan maksimum sekitar $5 \%$. Kadmium yang terdapat di biota belum tentu berasal dari pencemaran, karena secara alami kadmium ada di bebatuan. Pencemaran kadmium biasanya berasal dari industri pelapisan anti korosif, baterai, pewarnaan, stabilizer dan campuran logam (alloy) (Stoeppler, 1991).

Kerang darah di Tanjung Pasir yang mengandung kadmium kemungkinan berasal dari polusi limbah industri atau peluruhan mineral dari bebatuan. Kandungan Cu pada kerang yang diambil pada bulan Juni adalah 3,72 ppb dan pada bulan Oktober 22,0 ppb. Cu diperlukan dalam tubuh manusia dalam jumlah terbatas. Adapun kandungan $\mathrm{Pb}$ pada bulan Juni 13,96 ppb dan pada bulan Oktober 116 ppb. Pada bulan Oktober kandungan $\mathrm{Pb}$ dalam daging kerang sangat tinggi, hal ini kemungkinan disebabkan turunnya hujan yang membawa $\mathrm{Pb}$ dari buangan gas bahan bakar kendaraan bermotor dan buangan limbah industri dan tanah yang mengandung $\mathrm{Pb}$ (Ewers \& Schlipkoter, 1991).

Hasil pengamatan presumtif coliform pada air laut dan sedimen disajikan pada Gambar 3. Presumtif coliform pada air laut lebih dari $10 \mathrm{MPN} / 10 \mathrm{ml}$ pada bulan Juni dan Oktober, sedangkan pada sedimen dari perairan Tanjung Pasir pada bulan Juni kurang dari $10 \mathrm{MPN} / 10 \mathrm{ml}$ dan pada bulan Oktober lebih dari 10 MPN/10 ml. Coliform merupakan indikator pencemaran perairan, walaupun asal pencemaran ini dari limbah industri rumah tangga. Kerang darah telah terkontaminasi oleh coliform, sebesar 116 MPN/10 $\mathrm{ml}$ tetapi belum terkontaminasi oleh $E$. coli.

Kedalaman pantai Tanjung Pasir yang berjarak 1 mil sekitar 3,6 m, sedangkan pada jarak 2 mil sekitar $8,9 \mathrm{~m}$. Hasil pengamatan oksigen terlarut (DO) dan kebutuhan oksigen kimiawi (COD) di perairan Tanjung Pasir yang dilakukan pada bulan Juni dan Oktober 2001 seperti disajikan pada Gambar 4. Pada bulan Juni kandungan oksigen terlarut (DO) cukup tinggi, yakni $11,87 \mathrm{mg} / \mathrm{L}$ pada jarak $1 \mathrm{mil}$ dan $12,63 \mathrm{mg} / \mathrm{L}$ pada jarak 2 mil, sedangkan pada bulan Oktober kandungan oksigen terlarut (DO) pada jarak 1 maupun 2 mil rendah, yaitu $3,7 \mathrm{mg} / \mathrm{L}$. Apabila dikaitkan dengan kebutuhan oksigen kimiawi (COD) yang merupakan salah satu parameter pencemaran, pada bulan Juni maupun Oktober, kandungan COD pada jarak 1 mil maupun 2 mil hampir sama, berkisar $12,87-14,4 \mathrm{mg} / \mathrm{L}$. Nilai ini masih di bawah ambang batas pencemaran untuk perairan yaitu sebesar 40 $\mathrm{mg} / \mathrm{L}$. Hal ini berarti bahwa rendahnya DO pada bulan Oktober bukan semata-mata disebabkan oleh 


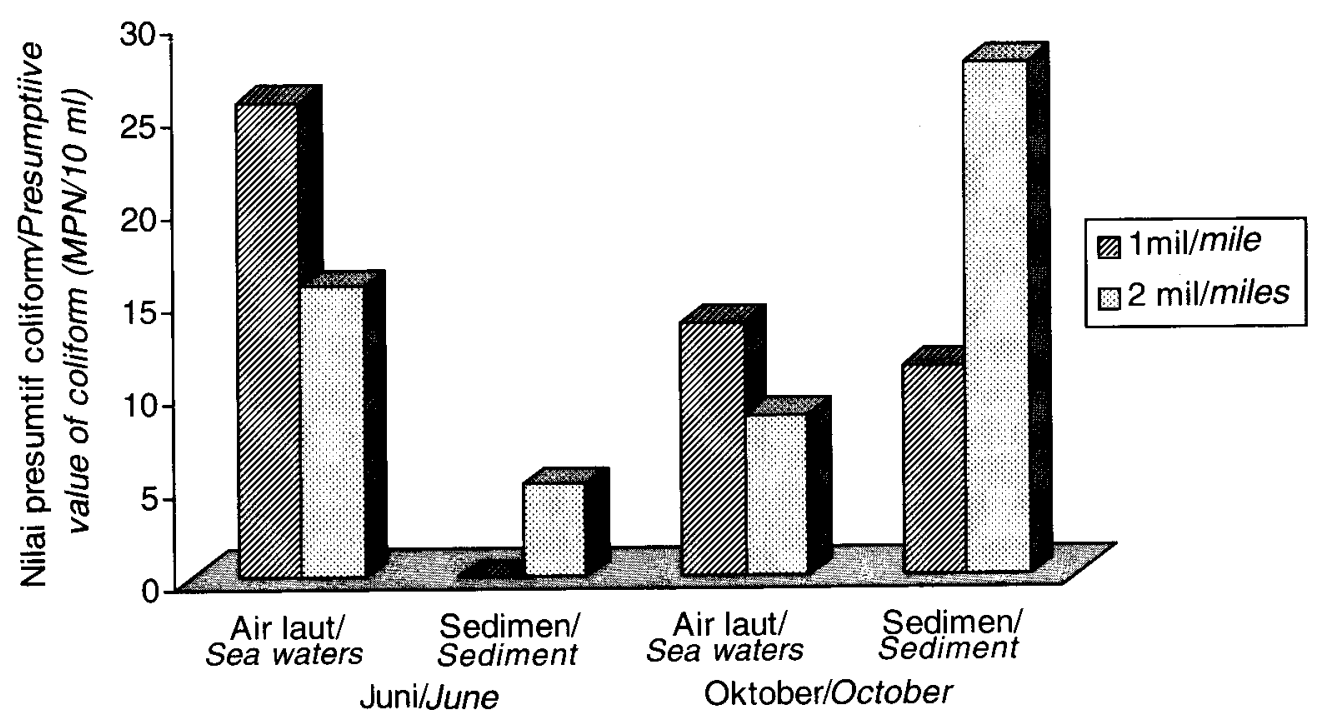

Gambar 3. Nilai presumtif coliform ( MPN/10 ml) di perairan Tanjung Pasir.

Figure 3. Presumptive value of coliform in Tanjung Pasir waters.

tingginya bahan buangan organik yang menggunakan oksigen terlarut untuk mengoksidasi bahan organik tersebut, tetapi lebih disebabkan oleh kemungkinan lain seperti terjadinya perubahan suhu perairan, tekanan udara maupun proses fotosintesis fitoplankton. Peningkatan suhu perairan akan menurunkan kelarutan oksigen (Kristanto, 1999;
Effendi, 2003). Penurunan tekanan udara akan menurunkan tingkat difusi oksigen dari udara ke laut, sedangkan peningkatan aktivitas fotosintesis oleh tumbuhan air dan fitoplankton akan meningkatkan oksigen terlarut (Effendi, 2003). Meskipun demikian, suhu perairan, tekanan udara maupun kelimpahan plankton tidak diamati selama kegiatan di lapangan.

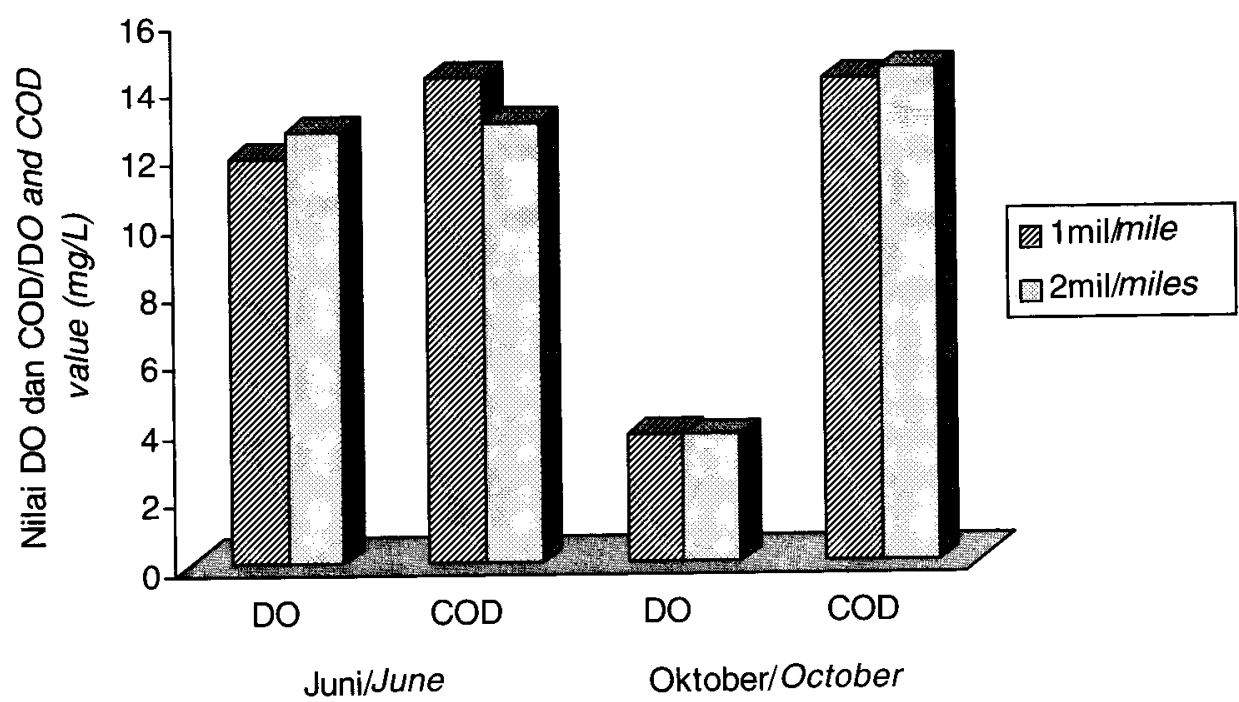

Gambar 4. Nilai DO dan COD di perairan Tanjung Pasir.

Figure 4. DO value and COD in Tanjung Pasir waters. 
Hasil pengamatan $\mathrm{pH}$ dan salinitas di perairan Tanjung Pasir yang dilakukan pada bulan Juni dan Oktober 2001 seperti disajikan pada Gambar 5. Nilai pH di perairan Tanjung Pasir pada bulan Juni dan Oktober yang berjarak 1 mil dan 2 mil berkisar 8,08,5 , sedangkan nilai salinitas relatif sama antara bulan Juni dan Oktober yaitu 29,7-33,3 ppt baik pada jarak satu maupun dua mil dari garis pantai. Nilai $\mathrm{pH}$ hasil pengamatan ini belum menunjukkan terjadinya pencemaran karena sebagian besar biota akuatik menyukai perairan dengan $\mathrm{pH}$ 7-8,5 (Effendi, 2003). Menurut Kristanto (1999), nilai pH yang normal adalah

\section{DAFTAR PUSTAKA}

Anonymous. 1995. Regulation of the production of uncooked, fermented meat product, food safety and hygiene. A Bulletin for the Australia Food Industry. http:/ /www.dfst.csiro.au/fshbull/fishbull 2. htm. $5 \mathrm{pp}$.

Anonymous. 1998. Compedium of fish and fishery product. Processes, Hazards and Controls $1^{\text {st }}$ ed. Chemical Hazards and Controls. Raleigh, NC, USA: National Seafood HACCP Alliance for Training and Education. $23.2 \mathrm{pp}$.

Anonymous. 2000. Toxic effects of some heavy metals. Water pollution menu page. http.//crucial.red. edu.nk/ pollute/metal.nun.

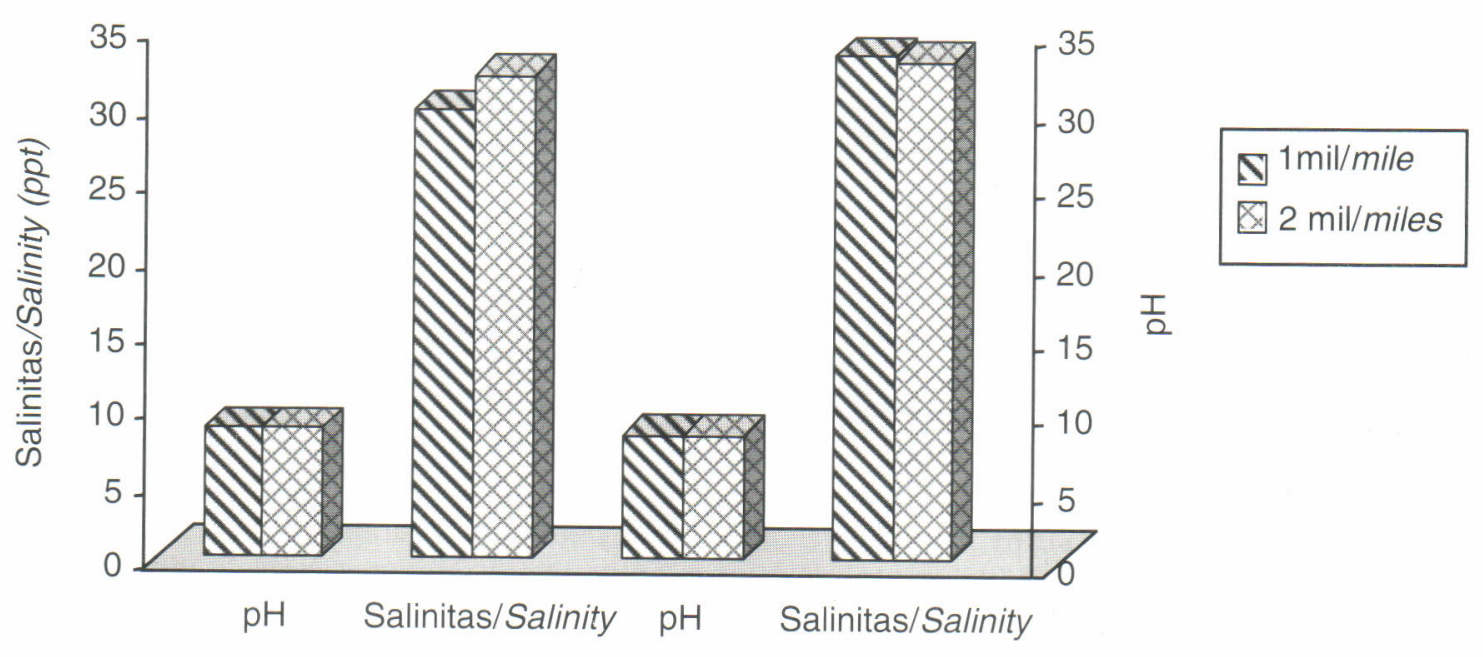

Juni/June Oktober/October

Gambar 5. pH dan salinitas di perairan Tanjung Pasir.

Figure 5. $\mathrm{pH}$ and salinity in Tanjung Pasir waters.

sekitar netral (6-8), sedangkan pada air tercemar nilai $\mathrm{pH}$ berbeda tergantung kepada jenis limbahnya.

\section{KESIMPULAN}

Dari hasil penelitian ini dapat diambil kesimpulan bahwa kerang darah yang hidup di perairan Tanjung Pasir pada saat pengambilan contoh pada bulan Juni dan Oktober 2001 belum menunjukkan terjadinya pencemaran logam berat. Kandungan logam merkuri, arsen, tembaga, kadmium dan timbal dalam kerang masih dalam batas aman untuk dikonsumsi. Perairan di Tanjung Pasir masih belum menunjukkan pencemaran baik dari kualitas air maupun kandungan logam beratnya, kecuali kontaminasi oleh coliform dan bukan kontaminasi oleh E. coli.
Effendi, H. 2003. Telaah Kualitas Air Bagi Pengelolaan Sumber Daya dan Lingkungan Perairan. Kanisius, Yogyakarta. p. 68-112.

Ewers dan Schlipkoter. 1991. Lead. In Merian, E. (ed). Metal and Their Compounds in the Environment. $\mathrm{VCH}$ New York. 1438 pp.

Graham, H.D. 1980. The Safety of Food. The AVI Publishing Co. Inc., Westport-Connecticut

Hutagalung, H.P. 1984. Logam berat dalam lingkungan laut. Oseana. 9(1): 11-20.

Hutagalung, H.P., Setiapermana, D. dan Riyono, S.H. 1997. Metode Analisis Air Laut, Sedimen dan Biota. Buku 2. Pusat Penelitian dan Pengembangan Oseanologi. LIPI. Jakarta. $181 \mathrm{pp}$.

Irianto, H.E., Fawzya, Y.N., Priono, B. and Sarnianto, P. 1987. Preliminary studies on the effect of environmental aspects on cockles quality in Cilamaya wa- 
ters Subang, West-Jawa. Journal of Post Harvest Fisheries Research. (59): 15-19.

Irianto, H.E. dan Poernomo, A. 2000. Keamanan konsumsi produk perikanan. Warta Penelitian Perikanan. 6(2): 5-7.

Kristanto, P. 1999. Ekologi Industri. ANDI, Yogyakarta. p. 71-96.

Raharjo,S. 1999. Detention of food exported from Indonesia to the USA by FDA in 1998. J. Indonesia Food and Nutrition Progress, 6(2): 59-63.

Stoeppler, M. 1991. Cadmium. In Merian, E. (ed). Metal and Their Compounds in the Environment. VCH New York. 1438 pp.

Tsubaki,T. dan Irukayama, K. 1977. Minamata Disease : Methylmercury Poisoning in Minamata and Niigata, Japan. Kodansha Itd., Tokyo. 130 pp.
Wahyuni, I.S. dan Hartati, S.T. 1991. Penelitian kualitas perairan pantai barat Teluk Jakarta. Prosiding Temu Karya IImiah Perikanan Rakyat, Jakarta 18-19 Desember 1989. Buku II. Jakarta: Puslitbangkan; 263-27.

Wahyuni, I.S., Hartati, S.T. dan Murniyati 1993. Pengaruh pencemaran terhadap pertumbuhan kerang hijau (Perna viridis) sebagai satu telaah studi baku mutu lingkungan perairan laut. Bull. Pen. Perik. Edisi Khusus. (4): 139-146.

Yong, L.P. 1992. Coliforms and Escherichia coli. In Miwa, K. (ed). Laboratory Manual on Analytical Methods and Procedures for Fish and Fish Products. 2nd Edition. Marine Fisheries Research Department Southeast Asian Fisheries Development Center Singapore and JICA. p. E 3.1 
